\title{
Battling Villagers in the Midst of Modern Life in Mata yang Enak Dipandang by Ahmad Tohari
}

\author{
M. Yoesoef \\ Department of Literature \\ \{yoesoev@yahoo.com; yoesoev@ui.ac.id\} \\ Faculty of Humanities, Universitas Indonesia
}

\begin{abstract}
This discussion aims to present the descriptive analysis of five short stories by Ahmad Tohari in the collection of short stories of Mata yang Enak Dipandang. Well-known for stories richly depict the life of villagers, the short stories reveal the struggles behind a seemingly homogeneous, innocent, and simple village culture with individualistic, heterogeneous, and complexed modern life. The two collide and boil down to the behaviors and reasons that represent the struggles of personal identity and its survival in the late modern life settings. It is within that context, Ahmad Tohari presents different layers of personal struggles of identity that is always faced with challenges to adapt and change in the midst of their respective era.
\end{abstract}

Keywords: Personal identity, Survival, Modern, Late modernity.

\section{Introduction}

In a story, the first thing a reader thinks of is what the story tells about and who are involved in the story. After that, how the story unfolds and how it ends. The horizon of the readers hopes, however, may not be based upon these thoughts but merely out of curiosity about the development of a literary creative process. Through reading a writer's latest literary works one could obtain a point that marks the journey of the writer's creativity. Perhaps things like that are awaited by readers of Ahmad Tohari's works.

This writer came to the platform of the Indonesian literary world through the story of Srintil who first appeared before readers as a serial story on Kompas newspaper. Then, the story of Srintil was born in the form of a novel and since then two other novels were born, making up the Ronggeng Dukuh Paruk Trilogy, consisting of Ronggeng Dukuh Paruk (1982); Lintang Kemukus Dini Hari (1985); and Jentera Bianglala (1986). The trilogy became the canon of his time. Before penning the trilogy, Ahmad Tohari had produced a novel titled Kubah (1980). Since then, his creativity seemed unstoppable, and his later works were born, such as Di Kaki Bukit Cibalak (novels, 1986), and a number of short stories published in various mass media (newspapers and magazines) and collected in Senyum Karyamin (collection of short stories, 1989); Bekisar Merah (novel, 1993), Lingkar Tanah Lingkar Air (novels, 1995), Nyanyian Malam (collection of short stories, 2000), Belantik (novels, 2001), Orang-orang Proyek (novels, 2002), Rusmi Ingin Pulang (collection of short stories 2004), and Mata yang Enak Dipandang (collection of short stories, 2013). 
Judging from Ahmad Tohari's works, it can be seen that there is a strong tendency that later became the hallmark of this writer, that is he always presents villagers who in touch with modernity. From such backdrop he presents various social, cultural, economic, and even political problems. Issues about environment, religion, or tradition are present as an inseparable part of the characters he tells. The life of the characters created by Tohari in his short stories or novels always raise a cultural identity before the reader.

To show how the village people were told by Tohari and what problems are revealed through the figures, this paper discusses a short collection of Ahmad Tohari's stories titled Mata yang Enak Dipandang (Gramedia, 2013). The collection of short stories contains fifteen stories that have been published in the mass media, such as Kompas daily and Kartini magazine between 1983 and 1997. The fifteen short stories are "Bulan Kuning Sudah Tenggelam” (1983), "Daruan” (1990), "Mata yang Enak Dipandang” (1991), "Bila Jebris Ada di Rumah Kami" (1991), "Penipu yang Keempat" (1991), "Warung Penajem" (1994), "Pemandangan Perut" (1994), "Kang Sarpin Minta Dikebiri” (1996), "Paman Doblo Merobek Layang-layang" (1997), "Salam dari Penyangga Langit" (2003), and there are five short stories that don't include year numbers, viz "Akhirnya Karsim Menyeberang Jalan," "Sayur Bleketupuk," "Rusmi Ingin Pulang," "Dawir, Turah, dan Totol," and "Harta Gantungan."

\section{Research Method}

In this article, the object of discussion is the short story as primary data. The data were analyzed using qualitative analysis, which is a research technique that directs the discussion to the contents of the text itself [1]; [2]. The qualitative analysis process is carried out as follows. It starts by reading the short story text intensively then describing the parts that will be discussed, then interpreting the text by looking at the literary context. Qualitative analysis is an analysis of the text (literature) to obtain the implied meaning and the discourse behind what is implied. For this reason, a number of relevant theories are needed to interpret the text. In this article the theories used are based on the sociology of literature approach, such as philosophical theories of personal identity in relation to theory of social structure of late modernity, as proposed by Giddens. Those theories are used to analyze the text since one's identities are formed through socialization process in their community which reflect social conditions, space, and environment. This approach views the text (literature) as a social document that describes a situation or condition that can be referred to a number of social, cultural, and political phenomena outside the text (literature) [1].

\section{Results And Discussion}

In this paper, five out of 15 stories are discussed. They are "Mata yang Enak Dipandang," "Bila Jebris Ada di Rumah Kami," "Penipu yang Keempat," "Warung Penajem," and "Akhirnya Karsim Menyeberang Jalan." These stories are chosen because they depict dynamic battles of personal identity of villagers within the contexts of late modernity. The diversity of such battles does not only illustrate harmony but also disharmony within the individuals, their community, as well as their continuance as persons.

In "Mata yang Enak Dipandang," the story of Mirta and Tarsa, a couple of beggars, is presented. Beggars are often associated as humans who earn a living by "peddling" their 
suffering, both physically and socio-economically. Their target is a group of people who are physically and socio-economically far better and more established. Interaction between the two groups takes place in public spaces, such as markets, terminals, crossing bridges, crossroads, and sidewalks that are considered strategic to earn sustenance from pedestrians. However, in that short story, Tohari talks about Tarsa who tended to impose his will on Mirta, who was blind and very dependent on him, his sighted guide. Tarsa often "cruelly" put Mirta in a difficult situation in order to get what he wanted, as stated in the following quote, "However, Mirta soon realized that Tarsa had deliberately left himself in a hot and difficult place. Roasting Mirta on asphalt is blackmailing and this time for a glass of lemonade" (p.9). Mirta's awareness that he was blackmailed was another aspect presented by Tohari to provide a balanced view of the two characters. Tarsa's victory over Mirta's suffering has presented a powerful image of powerlessness on the one hand and abuse on the other, as shown in the following quote.

\footnotetext{
"It's hot, Kang Mirta?"

"It's boiling, son of a bitch!" said Mirta in a dry, faint voice.

"Now you want to buy me lemonade, don't you?"

Mirta doesn't answer. However, Tarsa understood that Mirta could no longer stand under the sun. Tarsa also knew that Mirta surrendered. So, without bargaining again Tarsa took Mirta across and stopped near the drink seller. He drank a glass of lemonade with a sense of victory. Mirta also drank. Not lemonade but water" (p.11).
}

Mirta and Tarsa were juxtaposed with their respective roles that needed one another. The pairing itself is based on a transactional motivation, especially from Tarsa. Tarsa's transactional spirit was well manifested because he did not have any skills. At least he depends his income on Mirta's blindness and the charity of those who give money to Mirta. Tarsa used Mirta's weaknesses as well as his income capital. This was revealed by Tarsa who once said, "But your money is gone, and we haven't eaten yet. You haven't given me any wages, either." Tarsa positioned himself as a wage worker who sold his services, namely his sight, reliable physical strength, and unlimited mobility, and Tarsa knew very well how to use them to get the upper-hand of Mirta. Often times they also caused frequent debates between the two, especially about who took advantage of whom, about views and opinions regarding begging tips, especially at the train station. As an instance, Tarsa argued that the best time to get good money was when the first-class train arrived. On the contrary, Mirta preferred waiting for the third-class train. According to him, its passengers have generous eyes-eyes that were pleasing to see. The passengers of the first-class train, according to him, had cold eyes like bamboo eyes, eyes that were sorry for having come across a penniless figure, eyes that seemed to come from a very distant world.

Why do eyes become important in this short story? This is where Tohari metaphorically explored sight in an interconnected context, between perception mechanism and personal contexts. Mirta, whose sense of sight did not work, thought that eyes of a giver mattered even though he could not see them. This visual imagery of Mirta's was potentially developed through a process of image creation that is not resulted from any visual activity or that is restricted within language-like descriptions, rather from the "mind's eye" [3]. Seeing with "mind's eye" or having mental imagery is evidenced both in sighted and visually impaired individuals. Several studies found within visually impaired individuals, mental images are formed by sensory and memory representations as results from learning and personal experiences [4]. From experience, Mirta learned that third class train passengers stretched out their hands to him. He never saw their eyes, but he could "see" them. Therefore, this story does not talk about physical eyes. In fact, there is more to it even beyond autobiographical 
experiences of Mirta. Those pleasing eyes also represent Mirta's perception of his personal identity which he longed to relate to a particular group of people or a society in a sense. Drawing from John Locke's concept of personal identity [5], John Perry's refutation of Locke's ideas [6], and Brisset \& Edgley's definition of personal identity [7], Little et al. summarized personal identity as "the sense of personhood that places each of us uniquely in social context" [8]. They further elaborated this concept as follows.

"The sense of identity is thus the sense of agency, the sense of what it is to be this willing, choosing and acting entity, both now and in the future. Identity is the sense of being this person, with attributes (such as gender, physique, intelligence, endurance, health), acquisitions (such as wealth, property, rank, education, training, achievements), and capabilities (including work, power, vulnerability, reputation, status, approval) which condition interactions between the person and the social systems in which he or she lives. It is constructed and experienced by the person, but its experience is constructed and modified by events and associations within which the person moves. At the same time, different perceptions of personal identity are assigned to the person by others, and the subjective sense of identity and the external perceptions of identity engage reflexively with each other" (p.171).

The above prescription of personal identity implies that personal identity is formed by a dialogue between self and its social contexts. To take one's personal identity away from social contexts is to alienate the person. Therefore, although for Tarsa, it was all about getting more money from train passengers who were identified as the haves, for Mirta, as a poor blind person, it was more than getting some money; it was about being related to other people and not being alienated.

Hence, Tohari intrigues readers with an irony. Mirta and Tarsa were pictured to have a shared identity as a couple of beggars, but their personal identities are different and even at the opposite ends right to the point of getting money for survival. Their relationship was nothing more than a symbiotic mutualism that depicts the cruelty of transactional behavior. Tohari started the story with a sense of strong psychological connected between Mirta and Tarsa, but as Tohari closes the story with Mirta becoming seriously ill, due to Tarsa's roasting him under the sun, he brings the complexity of human beings beyond personal connections at a psychological level or even shared identities. Personal motives and values, may they be moral/ethical or political, are known to be significant factors that drive human behavior [9]. Different actions and motives to survive, both in physical and metaphysical realms, can be seen in the short story titled "Penipu yang Keempat" or the fourth imposter. The helpful attitude of "I" character, or the first person in the story, needs to be reinterpreted with a cautious manner. The story begins with the arrival of a person who claimed to be returning to his village in Cikokol. Apparently, he was the third person who came to ask for help from "I". It means it was third time "I" was visited by people who asked for his help. The surprising appeal of this story is the motivations of the three "con artists" or even fourth one with their respective modus of operandi (MO).

The first MO was represented by a female figure who brought a donation folder and introduced herself as an envoy from a foundation to care for orphans in Banyuwangi, East Java. The second MO was carried out by male figures who brought handicrafts produced by children with disabilities. In the third MO, a new male figure who was an acquaintance of "I" asked for financial assistance to be able to return to his village in Cikokol because his son was sick. Although those three figures seemed to have morally justified motives, the story reveals that those MOs were used to deceive "I" so that each figure could get financial gain from "I". However, at the end of this short story, Tohari surprises the readers with the figure of the fourth deceiver or con artist, namely the "I" character her/himself. Appeared to be a 
"philanthropist", "I" had her/his own MO as shown in following excerpt:

"However, what would happen if the Cikokol people knew that there was another con artist who was far smarter, namely he who today gave 14,000 to three amateur con artists. With Rp14,000 he hoped that God could be deceived and then bless him with money, no matter in what way the money was obtained. And I'm sure that only a true con artist can be very aware of his own deception" (p.38).

While giving help to the three persons who came to her/him, "I" secretly knew that all three were deceiving her/him. Nonetheless, "I" decided to accept their lies because s/he was looking for rewards. An act of altruism and even religiosity was worth no more than a transactional attitude or economic motive. The way Tohari chooses to present the character with the $1^{\text {st }}$ person pronoun only magnifies the message of the story, egoism. Here the story appeals to the classical theory of psychological egoism which asserts that humans' acts including what is considered as altruism are always driven by self-interests [10]. It compels the somber reality that behind our behaviors are hidden a very selfish motive that looks for reward and pleasure, whether in this life, as the first three con artists, or perhaps putative afterlife, as "I" was after. Tohari certainly cannot be claimed to hold the premise of psychological egoism, but at least his story acknowledges that egoism, especially such that is formed by religious beliefs and values, is a deceit before God. What "I' believed as true and valuable was realized as nothing other than pure egoism. Hence, we see values as the core of personal identity [11].

That is also depicted in the short story "Warung Penajem" which presents an inner conflict of the Kartawi figure (a farmer) when he was confronted with the hard work of Jum (his wife) who was trying to realize what she aspired to have. Kartawi was so occupied by his wife's ambitions that their relationship was often in trouble. Jum aspired to have a brickhouse, a television, and a motorcycle. Since she was a child, Jum loved playing stalls with her friends. When she married Kartawi, one of her requests was to have a real stall, which she could use to keep her busy while selling daily necessities. Meanwhile, Kartawi worked as a farmer by working on his dry farmland.

At first, Kartawi and Jum lived happily and harmoniously. Jum was willing to work hard and made every effort to make their stall grow and get a lot of buyers. As part of her efforts, she was also seeing someone who was known as having supernatural abilities from a nearby village, namely Pak Koyor, without the knowledge of her husband and other villagers. Since then, her business grew significantly that in the third year, she was able to build a brickhouse and bought a television in the following year. The only thing that she could not afford yet was a motorcycle. Kartawi fully supported his wife's business. In fact, he believed that if they had a motorcycle, it would certainly improve his image, unrivaled by fellow farmers in his village.

However, rumor had it that Jum gave a 'penajem' (sex offering) to a shaman in order to make her stall grow substantially. The rumor undoubtedly affected Kartawi and his work, and he could not bear to hear from his wife himself.

"What I gave to Mr. Koyor is not really that. I'm just playing around, just pretending. Not whole heartedly. Kang, I'm still sane. The real 'thingy' is only for you. Really, Kang." [....]

"Then, what's the difference between playful 'thingy' and real 'thingy'?" [...]

"Oh, dear, there's a lot of difference. Because it was just playing around, I didn't do it from my heart. My goal is only to pay 'penajem' so that our stall be in demand, nothing more. So, you don't lose anything, Kang. Everything is intact. "Kang, if our stall increases in demand, we would be prosperous, right?" (p.59)

Kartawi was not ready for that, so he escaped from the pressure. This is where Tohari once 
again presents a struggle of personal identity, this time between a husband and wife and their prominent identity in the community. As a husband, Kartawi wrestled whether to champion his identity as a husband and as wealthy farmer or as a man with intact moral integrity who refused to be deceived in such a way by his wife. At the end, he returned with a determination to choose his marriage along with the wealth that came from his wife's stalls over a personal identity that was detached from marriage institution and the appeal of a convenient and modern life. In the meantime, for Jum, the struggle was not personal identity per se, rather it was a matter between the advancement of her personal identity or a regress. She was after all had made peace with her moral reason for surrendering her body to Mr. Koyor as a 'penajem' when she decided to set her identity as a "modern" villager, and Kartawi was never an intrinsic factor that she considered from the beginning. In a nutshell, what seems to be a marriage crisis between husband and wife was reduced to a single crisis of a personal identity of Kartawi as a result of his wife's choice.

On another layer, this short story depicts a tension between a traditional social structure whereas shamans, such as Mr. Koyor, still have their place and modern life that heavily relies one's achievement as a logical consequence of their effort. In the background of the story, beliefs regarding fulfilling requirements given by a shaman in order to gain a success were also battling with concepts of modern life. Even though what Jum did confirms such practice still existed and was acknowledged, beliefs in shamans and super ordinary powers are losing their place in the society even amongst villagers, at least by social norm. It was seen by the reaction of Jum's neighbors who were gossiping about her using 'penajem'. It is an evidence that late modernity era has restructured the social structures not only in cities but also in villages, and inevitably it has impacted the dwellers as agency of the social structure. As Gidden argued that social structures or social systems of a society are in fact products formed by reflexive actions of its members [12]. Social structure and human agency form a duality in which each of their factors mutually affect the other. In other words, social systems are as dynamic as the members that live by them. In Modernity and Self-Identity, he argues that in this contemporary phase of modernity, marked by influx or information and education, we have transitioned into a post-traditional order where we engage in continuous reflexive constructions of our identity and no longer blindfoldedly followed an identity and role that the society assigns us [13]. Jum chose to actively reassign her role and identity in her marriage and in her community. It may not have been ethically or morally correct, but the issues brought up by Tohari are much more compelling than just moral issues: everyone in society, regardless of their genders, in micro or macro scale, can choose to shape their identity and in turn the identity of their society in this age of time.

Tohari further brings the dynamics between individuals and social structure in "Bila Jebris ada di Rumah Kami." The news that Jebris, a prostitute who planned to return and settle in her hamlet had raised concern her neighbors. While she was away, they had succeeded in getting rid of the label of their hamlet which was known as the birthplace of prostitutes. Her return was feared to bring back a disgrace to the village, and God's wrath would be upon them.

Through this short story, first, Ahmad Tohari brings back the collective memory that the people of the hamlet were about to forget. Apparently, that collective memory was still stored safely in the minds of the villagers. Only one small trigger was needed to bring it up to the surface. Memory has been linked to theories of personal identity from Locke to Parfit [14] [15] . A social group identity, just as personal identity, is formed by shared memory of the community. Fivush \& Graci argued that components of self-identity, such as personal themes, intention, and memory from childhood are socially mediated [16]. All together they construct 
what they call as narrative identity. Thus, remembering or reflecting to past events that shape personal as well as social identity is a common practice at those two levels. Fivush \& Graci further asserted that the act of remembering or reminiscing are threefold, i.e.: (1) it provides sociocultural norms of narrative practice that include sharing and co-constructing narratives with others; it creates structure or form for personal experiences that provide culturally mediated forms of narrative identity; and (3) is a means of creating social bonds that help create and maintain a sense of emotional coherence across time [16]. The conversation between Sar and her husband, Ratib, provides the narrative identity of their hamlet. Through reminiscing of their hamlet's social narrative, readers are brought to see how their struggle took forms even with the absence of Jebris.

Consequently, looking at Jebris' past and her identity in relation to her village, her return was not taken lightly by her neighbors. Accepting her would mean accepting a dark past that everyone in the village was trying hard to put behind. The voice of Sar, Jebris' childhood friend, is a voice of many villagers who were contemplating on their identity as a social group. Weeks believes that in essence identity is not neutral in itself [17]. It suggests that there is a tension underneath, a potential contradiction, because identity is self-identifying the one who holds it and the one who is against it. In this story, however, Tohari introduces another scheme: identity is not restricted to binary choice -an option between A or B. This is presented in the figure of Ratib. Ratib, who shared the same social identity with Sar and other villagers, saw Jebris' return not as a threat to their identity but as an opportunity to do good deeds to another human being that would basically please God. It suggests that identity is a complex matter that has multiple layers that allow it to adapt and even take another form through time, memory, and challenges. Therefore, placing one's identity and box it in a binary position is to defy human's basic identity.

As seen in stories of Jum and Jebris, every individual has personal identity that is always in dialogues with their society and its identity and those who live in it. The underlying tension can take any forms at any level -personal or society. In Jum's case, she opted for being a modern person while holding and practicing traditional beliefs. For Sar and Ratib, they opted for their community to hold true to traditional values of humanity, not just for any reasons, but for reasons that they considered were superior. Here identity is psychological, evens spiritual, as much as it is physical. This can be seen in the next short story.

In "Akhirnya Karsim Menyeberang Jalan," Tohari tells of the unfortunate event that happened to Karsim, a farmer, in the middle of the busy home coming traffic on a road that crossed his village, three days before Eid celebration. One day, Karsim was heading to his arable land and in so doing, he had to cross a very busy road full of passing vehicles. His farsighted eyes and awkwardness made it difficult for him to cross the road. Three times he tried and always failed. For the fourth time, he tried to cross it and got by a vehicle. He died on the scene.

Here Tohari presented the fate of Karsim who was killed on the road, among others the clash between the cultural behavior of the drivers and riders who were always on a hurry and Karsim's lack of anticipation and experience in dealing with fast moving vehicles. However, the clash was more than physical. It was also psychological as depicted in the following excerpt of the story:

"The main road was unusually congested by various vehicles especially those coming from the west. It was not easy for Karsim to cross....Car and motorcycle horns were shouting at him. Riders's faces are the faces of the street kings. The faces that carry all the symbols of a city: inflated ego, spoiled, and extraordinary deepness. Show off" (p.90). 
Here Tohari sharply observed the behavior of the drivers, as if they were disturbed by pedestrians, such as Karsim. Such attitude was contrasted and yet complemented by Karsim's consciousness. "So Karsim relented, waiting maybe there was a chance to cross. His awareness as a poor villager is nrimo" (p.). Nrimo is a term in Javanese philosophy which means one willingly accepts a situation or an outcome of it with acknowledgement that all is within God's sovereignty. This 'submissive' attitude which is closely associated with a traditional view of looking at life challenges clashed with the fastness and relentlessness of modern life. Who won? Tohari closes the story as in the following.

"But all slackened when the coffin carrying Karsim's body reached the side of the road. A young man proudly waved a yellow flag, then all vehicles from both west and east suddenly stopped ... in less than five minutes the coffin and his escorts had cut off the road. Karsim smiled. Only this time from birth until his death came this afternoon at the age of 69 years Karsim felt his existence was recognized. And he knows now, for his existence to be recognized by people he must first enter the coffin and be escorted to the cemetery" (p.93).

Tohari did not stop there.

"And Karsim was struck again when he saw a luxury car driven by a female monkey. Next to the wheel sat a fat man wearing a mouse head mask, even a boar. Karsim shook his head because it turned out that luxury cars that were driven by strange masked creatures; wild boar, wolf, mooch, monkey, continue passing by" (p.95).

Personal identity is both physical and psychological, and Tohari brilliantly tells this from a perspective of a dead man who saw what physical eyes otherwise miss. In so doing, he seems to hold the view that personal identity remains beyond physical existence. Even though Karsim had died, his personal identity as a person, a human being, remained -physically and psychologically.

\section{Conclusion}

The various problems addressed by Ahmad Tohari in the five short stories present issues that can be discussed in the context of personal identity and social identity, each of which is heavily influenced by their culture. Those identities are a matter of position in similarity and diversity [18], and to some degree they can be in conflict [19]. The characters with their respective identities, in principle, reflect and represent a particular cultural product that is inherent in a person or group of people. Behind the characters in each of Ahmad Tohari's short stories, readers meet ethical, moral, and social problems of the Indonesian people who are battling to form or re-form their identity in this late modernity era. Traditional values when paired with that of modern life always give birth to exotic stories.

The grand discourse that emerged from the discussion is that the stories show dialogues of how one's personal identity develops, adapts, and evolves in its respective age. This compelling collection of short stories of "Mata yang Enak Dipandang" reveals a very dynamic process of such adaptation and evolution. The battles are not always transparent to physical eyes. They must be seen through the "mind's eye" - the eye that potentially shapes our personal identity and in turn our social identity more than one can phantom. What Mirta and Karsim saw was that our identity is more than physical, rather it is psychological, and it may be eternal. In that context, what is unavoidable is that silently Tohari brings his readers to see themselves and their society with their "mind's eye" which in turn might indirectly skin their 
faces as individuals who live in this era of individualism. They could have the "eyes that are pleasing to see ", they could be monkeys, boars, wolves in disguise, or any forms that resemble their true motives and values. Perhaps, what Tohari appeals, as in the story of "Penipu yang Keempat", is readers and perhaps people in general might have the courage to come to terms with their true identity and motives of behavior and admit them, at least to themselves and even God in that matter.

\section{References}

[1] K. Krippendorff, Content Analysis: An Introduction to Its Methodology. London: Sage Publications, 2004

[2] K. A. Nuendorf, The Content Analysis Guidebook. London: Sage Publication, 2002.

[3] H. Bértolo, "Visual imagery without visual perception?," Psicológica, vol. 26, pp. 173-188., 2005.

[4] C. Renzi, C. Cornoldi, Z. Cataneo, and T. Vecchi, "Mental imagery and blindness," in Multisensory Imagery, S. Lacey and R. Lawson, Eds. Springer, 2013, pp. 115-130.

[5] J. Locke, An Essay Concerning Human Understanding. Chicago: Encyclopaedia Britanica, 1689.

[6] J. Perry, Personal Identity. Berkeley: University of California, 1975.

[7] D. Brisset and C. Edgley, Eds., Life as Theater: A Dramaturgical Sourcebook. New York: Aldine de Gruyter, 1990.

[8] M. Little, P. Kim, C. F. C. Jorden, and E. J. Sayers, "Survivorship and Discourses of Identity," Pshyco-Oncology, vol. 11, pp. 170-178, 2002.

[9] C. Kluckhohn, "Values and Value-Orientations in the Theory of Action: An Exploration in Definition and Classification," in Toward a General Theory of Action, E. Parsons, T. and Shils, Ed. Cambridge: Harvard University Press, 1951, pp. 388-433.

[10] W. Irwin, "Psychological Egoism and Self-Interest," Reason Pap., vol. 39, no. 2, pp. 68-69, 2017.

[11] S. Hitlin, "Values as the core of personal identity: Drawing links between two theories of self," Soc. Psychol. Q., vol. 66, no. 2, pp. 118-137, 2003.

[12] P. Smith, Cultural Theory: An Introduction. Oxford: Blackwell Publishing, 2001.

[13] A. Giddens, Modernity and Self-Identity. Stanford: Stanford University Press, 1991.

[14] D. Parfit, Reasons and Persons. Oxford University Press, 1984.

[15] M. Jungert, "Memory, Personal Identity, and Memory Modification," in Selbstgestaltung des Menschen durch Biotechnologien, S. Ranisch, R., Rockoff, M., Schuol, Ed. 2015.

[16] R. Fivush and M. E. Graci, "Memory and Social Identity," in The Routledge Handbook of Philosophy of Memory, 1st ed., S. Bernecker and K. Michaelian, Eds. Routledge Taylor \& Francis Group, 2017, pp. 268-280.

[17] J. Weeks, "The Value of Difference," in Identity, Community, Culture, Difference, Jonathan Rutherford, Ed. London: Lawrence \& Wishart, 1990, pp. 88-100.

[18] S. Hall, "Cultural Identity and Diaspora," in Identity: Community, Culture, Difference, J. Rutherford, Ed. London: Lawrence \& Wishart, 1990.

[19] K. Saddhono, "Language of Coastal Communities in the Northern Coast of Central Java: Sociolinguistic Studies in Cultural Integration Maritime-Agrarian Perspective." Adv. Sci. Let. vol. 23 no. 10 pp 10054-10056, 2017 